\title{
MAGNETIC FORCE MICROSCOPE IMAGE EVALUATION OF MAGNETIC IRON OXIDE FLOPPY DISC WITH VARIOUS LIFT HEIGHTS
}

\author{
Nanda Shabrina, Mardiyanto and Abu Khalid Rivai \\ Center for Science and Technology of Advanced Materials - BATAN \\ Kawasan Puspiptek, Tangerang Selatan, 15314 \\ E-mail: shabrina_n@batan.go.id
}

\begin{abstract}
MAGNETIC FORCE MICROSCOPE IMAGE EVALUATION OF MAGNETIC IRON OXIDE FLOPPY DISC WITH VARIOUS LIFT HEIGHTS. One of the advantages of Scanning Probe Microscopes (SPM) or better known as the Atomic Force Microscope (AFM) is its ability to "see" in detail at the level of atoms and molecules, so as to improve understanding of how a system works and leads to new discoveries in areas such as life science, materials science, electrochemistry, polymer science, biophysics, nanotechnology and biotechnology. To understand about the MFM mode, amplitude, phase and topographic image, a piece of a floppy disk as references sample was used in various lift heights. In this paper presented the principles of AFM work and explain the necessary components of such equipment. The MFM images were taken in floating operation method at different heights namely 30, 40 and $60 \mathrm{~nm}$ between the surface sample and Co-Cr cantilever tip. Result showed the distance between the cantilever tip to the sample surface influenced the image quality. The best amplitude image could be taken in $60 \mathrm{~nm}$ distance.
\end{abstract}

Keywords: Atomic Force Microscope, Non-contact mode, Topography

\begin{abstract}
ABSTRAK
EVALUASI CITRA MAGNETIC FORCE MICROSCOPE (MFM) OKSIDA BESI MAGNETIK DENGAN VARIASI JARAK. Salah satu keunggulan Scanning Probe Microscopes (SPM) atau lebih dikenal dengan Atomic Force Microscope (AFM) adalah kemampuannya untuk "melihat" secara terperinci pada tingkat atom dan molekul, sehingga dapat meningkatkan pemahaman tentang bagaimana suatu sistem bekerja dan mengarah ke penemuan baru di berbagai bidang seperti ilmu kehidupan, ilmu material, elektrokimia, ilmu polimer, biofisika, nanoteknologi dan bioteknologi. Untuk pemahaman mendalam mengenai mode MFM, amplitudo, fase, dan gambar topografi, floppy disk oksida besi magnetik digunakan sebagai sampel referensi dengan variasi jarak antara tip kantilever dengan permukaan sampel. Dalam makalah ini disajikan prinsipprinsip kerja AFM dan menjelaskan komponen-komponen penting dari peralatan tersebut. Citra MFM diambil dalam mode operasi floating (non-contact) pada ketinggian berbeda yaitu 30, 40 dan $60 \mathrm{~nm}$ diatas sampel permukaan dengan menggunakan tip kantilever Co-Cr. Hasil menunjukkan jarak antara ujung kantilever ke permukaan sampel mempengaruhi kualitas gambar. Citra amplitudo terbaik diambil dalam jarak $60 \mathrm{~nm}$.
\end{abstract}

Kata kunci: Atomic Force Microscope, Mode non-kontak, Topografi

\section{INTRODUCTION}

The development of magnetic nanomaterial has widely grown up in this decade for different technological application. The conventional technique to characterize the magnetic properties at nanometer scale was used VSM. New tools as MFM mode in AFM can be characterize the magnetic properties using the combination of the capability of positioning and imaging at nanometer scale [1].

MFM is one of the AFM imaging methods which is used to study magnetic material characteristic. Image 
result on the imaging process with MFM mode is basically the information contained in the laser beam deflection angle of the cantilever due to an interaction between the cantilever tip and the magnetic material sample. The cantilever tip is given a layer of magnetic material on its surface. The interaction between the magnetic material on the tip and the sample makes the cantilever be straight and bent. [2-5].

The interaction of cantilever tip-sample plays important roles in getting the data. When the tip is brought near the surface of the sample, there will be the interaction between the atom tip with the surface atoms. The atom at the tip very close to the sample atoms occur happen electrostatic repulsion and vice versa if the distance between the farther it is precisely the force of attraction is enlarged due to the van der Waals force [6]. For the contact method, the information deflection of the cantilever due to electrostatic forces, while for noncontact method utilizing weak van der Walls force.

However, in the floating method, the repulsive force between the atoms is very small to be able to image the surface topography of the sample. To solve this problem, it can be used to vibrate the cantilever piezoelectric modulator around the resonance frequency as close as possible to the sample surface and further correlate the changes to surface topography cantilever vibration [7]. The method was then referred to as the floating method, also known as the method of alternating current detection and proved to have a much higher sensitivity than the touch meth-od. One advantage of using the float method is very efficient use of the cantilever as the cantilever tip no physical contact with the sample surface so that no frictional forces that would erode or break the cantilever tip.

A reference sample should be useful for the determine the several important quantities in MFM such as magnetization polarity of the MFM tip, relative resolution and relative magnetic sensitivity [8]. The interplay of ferroic orders is one of the key properties that open large potential applications in memory and logic devices that can be controlled both electrically and magnetically. [9]

A reference sample should be useful for determining several important quantities in $M F M$ [8]. Yue et al reported the hard disk film (a reference sample from NIST as a reference samples to analyzed the hologram data from the magnetic stray field that originates from Co-Pt particles tip [10].

To understand about the MFM mode, amplitude, phase and topographic image, A piece of a floppy disk was used as a sample with the lift height is $30 \mathrm{~nm}$, which is well above the sample surface. To evaluate magnetic materials and devices or to locate and map magnetic defects on a variety of materials and surface with surface roughness value, the samples was investigated with AFM - MFM mode in PSTBM, BATAN.

\section{EXPERIMENTAL METHOD}

\section{Materials and Instruments}

A piece of a floppy disk was used as a sample with the lift height is $30 \mathrm{~nm}$, which is well above the sample surface. To evaluate magnetic materials and devices or to locate and map magnetic defects on a variety of materials and surface, the samples were investigated with AFM - MFM mode in PSTBM, BATAN.

\section{Method and Procedure}

In this MFM Mode of the XE-series AFM, each sample is scanned twice to separate the topographic and magnetic signal. In the firrst scan, the tip scans the surface as in True Non-Contact AFM to obtain the topography of the sample. In the second scan, the tipsample distance is increased and the biased tip is scanned along the topography line obtained from the first scan. The tip is only affected by the magnetic force. The cantillever type which was used to take the MFM image was a MFMR (Magnetic Force Microscopy Reflex) cantilever.

\section{RESULT AND DISCUSSION}

When XE-series AFM is operated in a floating method, it can be observed three types of signals: topography, NCM amplitude, and phase NCM. The topographical line maintains constant tip sample distance, which equals the line of the constant van der Waals force. So, when the tip follows the topography line in the second scan of 'MFM mode', the van der Waals forces acting on the tip are kept constant. Thus, the only change in force affecting the signal is the change of the magnetic force. So, from the second scan,
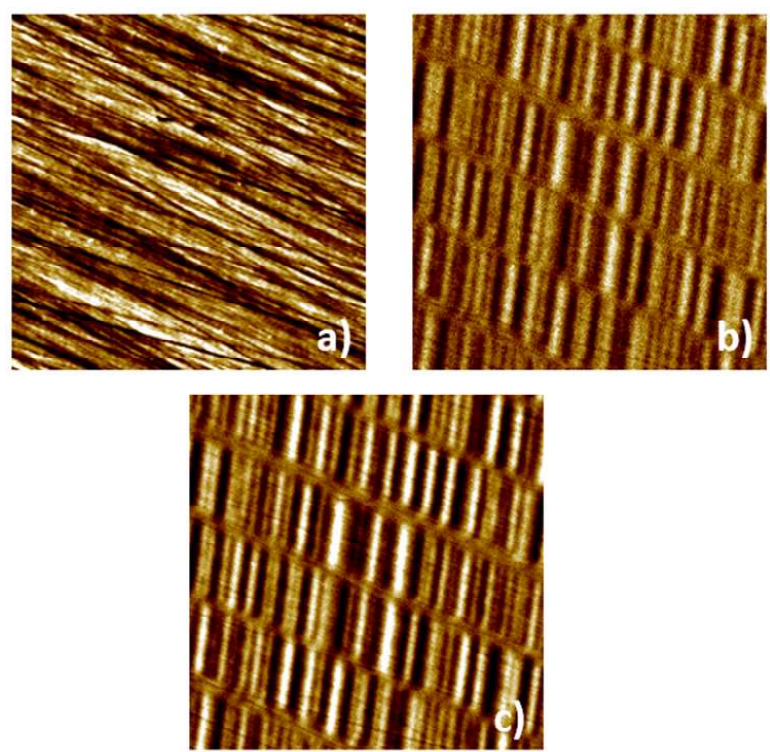

Figure 1. MFM image : (a). Topografi, (b). Amplitude and (c). Phase of a standard sample 
the MFM image, free of topography signal, can be obtained.

From Figure 1, the image shows the topography and amplitude information recorded and visible presence of the magnetic force distribution are arranged on a regular basis. This image is the result of the interaction between the cantilever tip that has been magnetized by the distribution of magnetization of magnetic materials. The distribution of this material is the result of recording the information on the sample. The image is different compare to the topographic image of the same surface position (Figure 1 (a) with Figure 1 (b) and (c)). The image (Figure 1 (a)) shows the topography of the valley and the hill which is a real condition, while the amplitude and phase image illustrate the distribution of surface magnetic force.

\section{Effect of the Height of the Cantilever-Sample Surface to Image}

AFM imaging results with MFM to float mode spacing variation of 30,40 and $60 \mathrm{~nm}$ between the cantilever tip with the sample surface can be seen in Figure 2, 3 and 4.

The sample is a piece of a floppy disk. In figure 2. (a), the lift height is $30 \mathrm{~nm}$, which is well above the sample surface. The individual bits recorded on the disk are clearly marked. However the topographic image is seen (compare Figure 2(a) and (c)). Figure 3 (a) shows the image at a lift height of 40nm for the same sample surface position; the topographic signals are still present, while the fine structure of the magnetic distribution starts to be significant. Figure 4 (a) shows the image produced when the Lift Height is $60 \mathrm{~nm}$. At this height, the
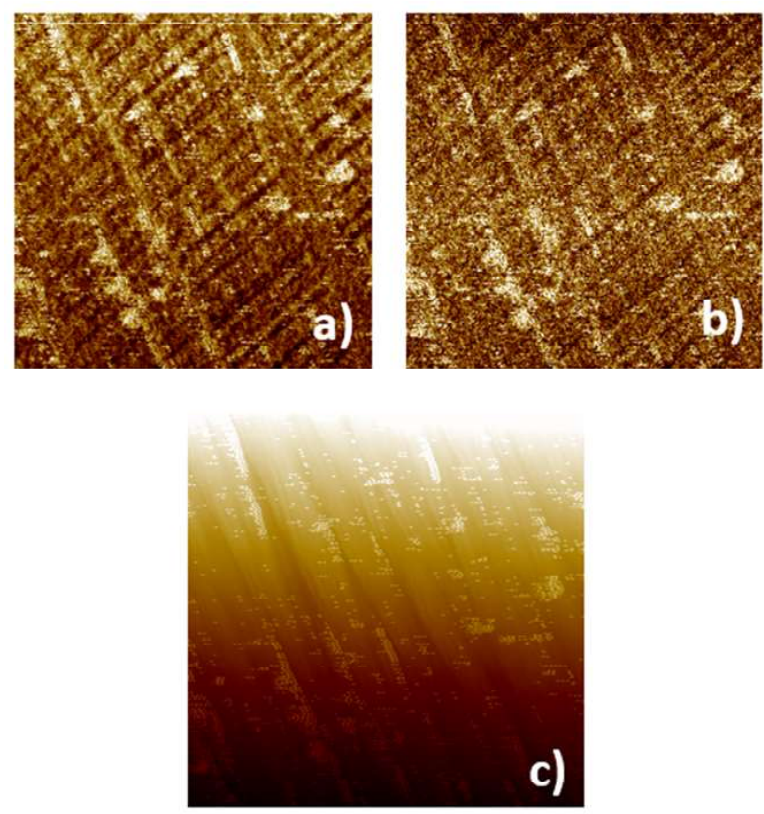

Figure 2. MFM images of the same region of the sample taken at Lift Heights of $30 \mathrm{~nm}$, in (a) amplitude, (b) phase, (c) topography mode.
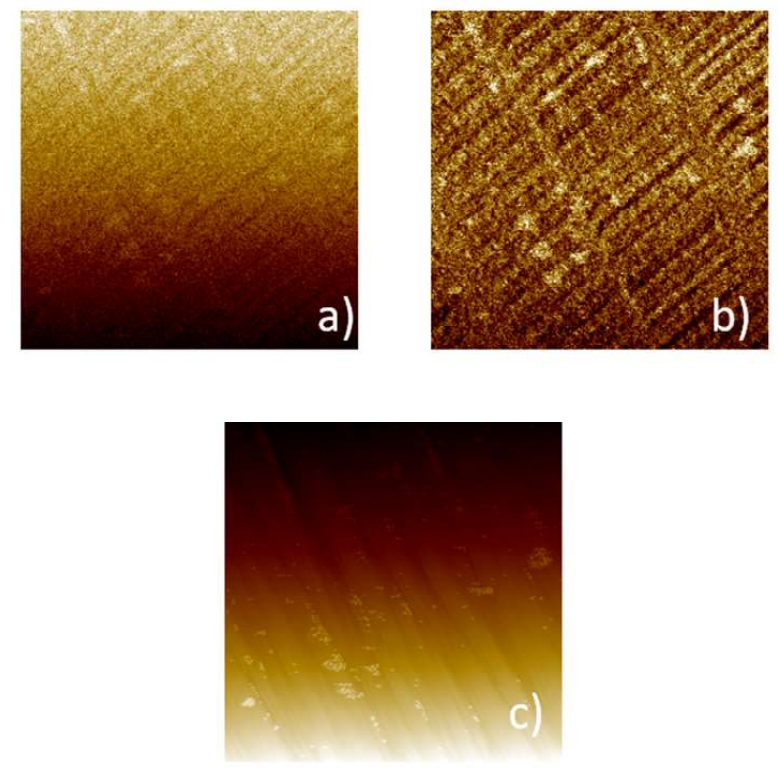

Figure 3. MFM images of the same region of the sample taken at Lift Heights of $40 \mathrm{~nm}$, in (a)amplitude, (b) phase, (c) topography mode.
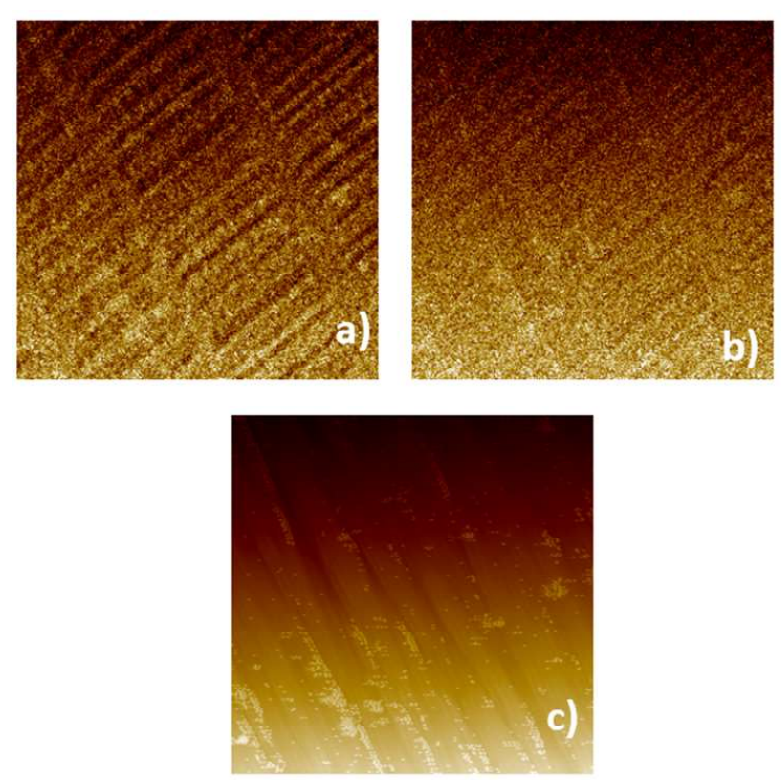

Figure 4. MFM images of the same region of the sample taken at Lift Heights of $60 \mathrm{~nm}$, in (a) amplitude, (b) phase, (c) topography mode.

contribution of the fine magnetic signals is shown clearly and the topographic signals disapear. At these conditions, we are measuring the local magnetic field. It shows that Figure 4(a) is the best magnetic image and Figure 2(a) contains both magnetic and top ographic signals due to the total deflection force on the cantilever is inluenced by both atomic and magnetic force.

Figure 5 shows the 3D image, topography and statistic data of the samples at lift height $30 \mathrm{~nm}, 40 \mathrm{~nm}$ and $60 \mathrm{~nm}$. Figure 5, it is shown that the Ra values (the 

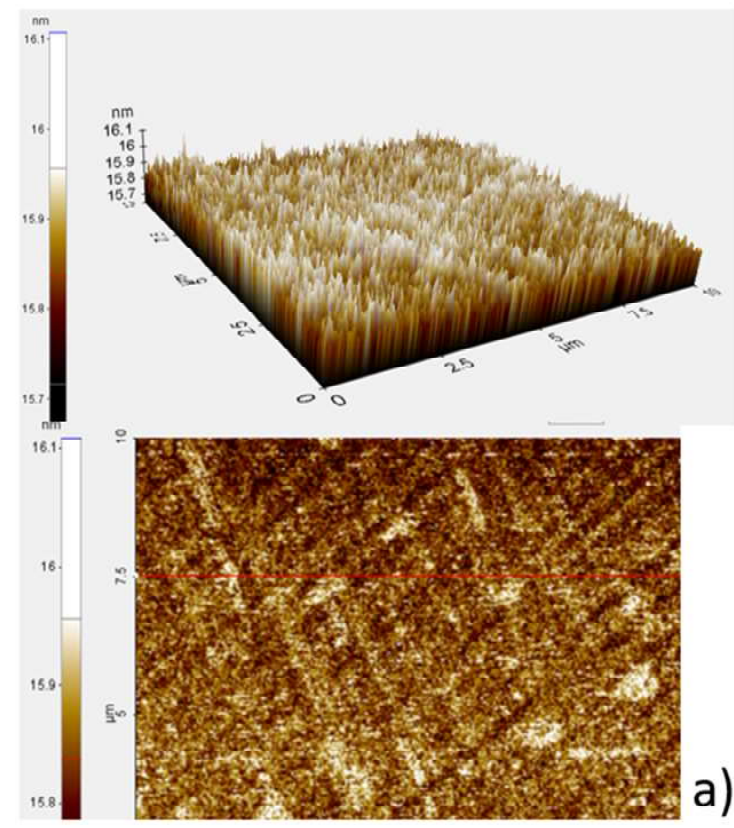

a)

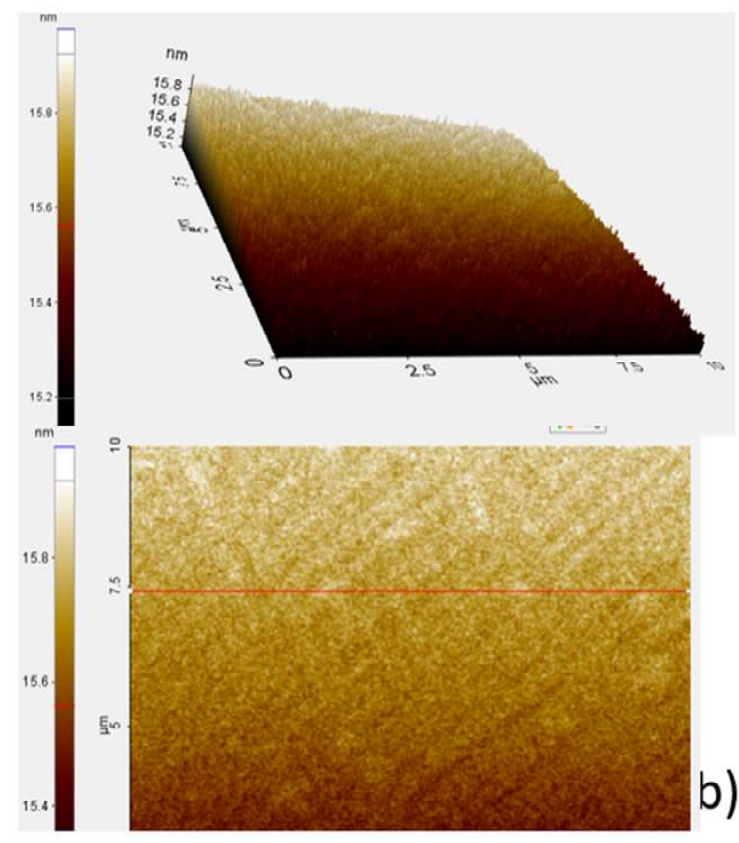

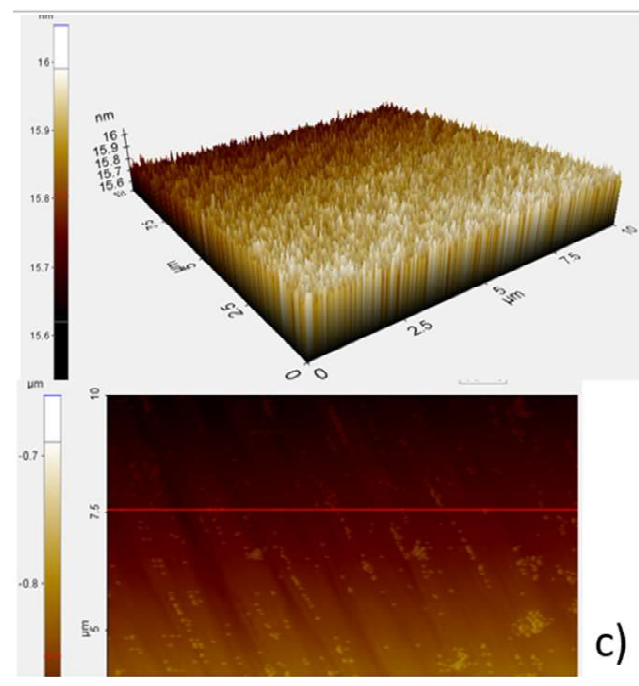

\begin{tabular}{|c|c|c|c|c|c|c|c|c|c|c|}
\hline Line & $\operatorname{Min}(n m)$ & $\operatorname{Max}(n \mathrm{~nm})$ & $\operatorname{Mid}(\mathrm{mm})$ & $\operatorname{Mean}(\mathrm{nm})$ & $\operatorname{Rpv}(\operatorname{mm})$ & $\mathrm{Rq}(\mathrm{nm})$ & $\operatorname{Ra}(\mathrm{nm})$ & $R z(n m)$ & Rsk & Rku \\
\hline$\nabla$ Red & 15.717 & 16.010 & 15.864 & 15.846 & 0.293 & 0.05 & 0.039 & 0.245 & 0.434 & 3.63 \\
\hline Line & $\operatorname{Min}(\mathrm{mm})$ & $\operatorname{Max}(\mathrm{nm})$ & $\operatorname{Md}(\mathrm{mm})$ & $\operatorname{Mean}(\mathrm{nm})$ & $\operatorname{Rpv}((\mathrm{nm})$ & $\mathrm{Rq}(\mathrm{rm})$ & $\operatorname{Ra}(\mathrm{nm})$ & $R z(n m)$ & Rsk & Rku \\
\hline Q Red & 15.609 & 15.858 & 15.734 & 15.734 & 0.250 & 0.04 & 0.034 & 0.204 & 0.000 & 3.005 \\
\hline Line & $\ln (n m)$ & $\operatorname{Max}(\mathrm{nm})$ & $\operatorname{Mid}(\mathrm{mm})$ & $\operatorname{Mean}(\mathrm{nm})$ & $(\mathrm{mm})$ & (nm) & $\operatorname{Ra}(\mathrm{rm})$ & $z(\mathrm{rm})$ & Rsk & Rks \\
\hline$\checkmark$ Red & 15.630 & 15.848 & 15.739 & 15.748 & 0.217 & 0.042 & 0.034 & 0.191 & -0.103 & 2.635 \\
\hline
\end{tabular}

Figure 5. 3D image, topography and statistic data in amplitude mode at the same line of the samples taken at lift heights of a) $30 \mathrm{~nm}$, b) $40 \mathrm{~nm}$, and c) $60 \mathrm{~nm}$.

arithmetical mean deviation of the roughness profile) are between 0.34-0.39 nm. AFM provides a precise nanometer scale range surface roughness, indicated by the values obtained not too far at different tip to samples distances.

\section{CONCLUSION}

Two parameters that influenced the image quality were the cantilever type and the distance between the cantilever tip to the sample surface. The best amplitude image could be taken when the tip to sample distance is about $60 \mathrm{~nm}$. The shorter the tip to sample distance the bigger the topographic signals appear. The surface roughness Ra values were $0.34-0.39 \mathrm{~nm}$.

\section{REFERENCES}

[1] L. Angeloni, D. Passeri, M. Reggente, D. Mantovani, and M. Rossi, "Removal of electrostatic artifacts in magnetic force microscopy by controlled magnetization of the tip: Application to superparamagnetic nanoparticles," Sci. Rep., vol. 6, no. May, pp. 1-14, 2016.

[2] U. Hartmann, "Magnetic Force Microscopy", Annual Review of Materials Science 1999, vol.29(1), 53-87, 1999

[3] T. R. Ferret, "Data Recovery from magnetic media using magnetic force microscopy," Statler College of Engineering and Mineral Resources, 2008.

[4] M. Nenadovic, S. Strbac, and Z. Rakoce, "Surface Texture Parameters in Optimizing Magnetic Force 
Images," Publ. Astron. Obs. Belgrade, vol. 84, pp. 197-200, 2008.

[5] M. V. Rastei, M. Abes, J. P. Bucher, A. Dinia, and V. Pierron-Bohnes, "Field-dependent behavior of a magnetic force microscopy tip probed by means of high coercive nanomagnets," J. Appl. Phys., 2006.

[6] F. L. Leite, C.C. Bueno, A.L. Da Roz, E.C. Ziemath, and O.N.Oliviera, "Theoretical Models for Surface Forces and Adhesion and Their Measurement Using Atomic Force Microscopy", Int J Mol Sci; 13(10): 12773-12856, 2012

[7] S.I. Moore, M.G. Ruppert, Y.K. Yong, "Multimodal cantilevers with novel piezoelectric layer topology for sensitivity enhancement," Beilstein J Nanotechnol. 2017;8:358-371, 2017.

[8] P. Rice and S.E. Russek, "Magnetic Imaging Reference Sample" IEEE Transactions on Magnetic, ol.32, No.5 September, 1996.

[9] H. Liu, R. Comes, J. Lu, S. Wolf, J. Hoodgson, M. Rutgers, "A versatile variable field module for field and angular dependent scanning probe microscopy measurements," Review of Scientific Instruments, pp. 1-15, 2013

[10] L. Yue, S. Liou. "Magnetic Force Microscopy Studies of Magnetic Features and Nanostructures" in Scanning Probe Microscopy in Nanoscience and Nanotechnology 2, NanoScience and Technology, B. Bhushan, Ed. Berlin: Springer, 2011, pp. 287-319. 